\title{
Preface
}

Telling Stories is written in a consciously interdisciplinary way by three University of Minnesota scholars-one historian, Mary Jo Maynes, and two sociologists, Jennifer L. Pierce and Barbara Laslett. The conscious choice to adopt an interdisciplinary perspective reflects interests we share with each other and with many scholars across the disciplines; it also reflects the influence of the feminist scholarly communities in which each of us has participated, separately and together. A language of interdisciplinarity and cross-disciplinary reading and conversation has been essential to the genesis and writing of this book.

Although we share an interest in personal narratives, the three of us have worked with different kinds of personal narrative evidence and analyses in our own research. M. J. began research on European working-class autobiographies in the 1980s. Her interest in personal narrative sources led her to join the interdisciplinary feminist research collaborative, the Personal Narratives Group, at the University of Minnesota; work with that group, which collectively wrote Interpreting Women's Lives (Bloomington: Indiana University Press, 1989), brought her into conversation with literary scholars working on personal narratives as well as with historians and social scientists. Her autobiography project culminated in Taking the Hard Road: Life Course in French and German Workers' Autobiographies in the Era of Industrialization (Chapel Hill: University of North Carolina Press, 1995). Jennifer combined ethnographic fieldwork and career life stories with paralegals and lawyers for her first book, Gender Trials: Emotional Lives in Contemporary Law Firms (Berkeley: University of California Press, 1996). She has also collected life stories from feminist academics for her co-edited volume, 
Feminist Waves, Feminist Generations: Life Stories from the Academy (Minneapolis: University of Minnesota Press, 2007) and she is currently working with the Twin Cities Gay, Lesbian, Bisexual, and Transgender Oral History Project. Barbara has published a series of articles based on her biographical research on the influential early twentieth-century American sociologist William Fielding Ogburn. With Barrie Thorne, she also commissioned and co-edited a collection of life stories from feminist sociologists: Feminist Sociology: Life Histories of a Movement (New Brunswick, NJ: Rutgers University Press, 1997).

Our theoretical concerns began with questions about individual human agency; interest in how this might be explored empirically was at the center of our early reading of analyses of personal narratives. We had grappled with questions about human agency in our own work; we knew that historians and social scientists from a variety of disciplines were increasingly using personal narrative evidence in their research, and that they were finding interesting new approaches to working with such forms of evidence. Since working with personal narratives was less common in the social sciences than in history, we also realized that there were many epistemological, theoretical, and methodological questions that we needed to address if we were to discuss how personal narrative analysis "works" for an interdisciplinary audience. We thus began a program of common reading and discussion of scholarship in history and the social sciences that uses personal narratives as their primary source of empirical data. We didn't choose the works we discuss in Telling Stories by following a particular system. Instead, we started from key works in our areas of research that we knew provided food for thought and would be the basis for productive interdisciplinary conversation. Since personal narrative research was particularly prominent in oral history and in interdisciplinary feminist scholarship, we drew heavily on publications in relevant publishers' catalogues and journals in these areas. We read widely, but our reading has always aimed to be exemplary rather than exhaustive.

We were also influenced by our individual political experiences, values, and intellectual priorities. We are of different generations. Barbara was born during the Depression of the 1930s and had become involved in left-wing politics in the immediate post-World War II period; she began her career in sociology before second-wave feminism emerged and was one of its pioneers. M. J. was a student during the social movements of the late 1960s and 1970s; her graduate studies were shaped by both "history from below" focused on the experiences of ordinary people and emergent feminist revisionism. Jennifer was a post-second wave feminist who did graduate work in the 1980s and whose scholarship has been influenced by feminist theory, feminist methods, and ethnographic studies of work. The books that interest us the most tend to reflect these orientations as well as our academic areas; we thus draw heavily on studies using personal narratives 
to examine class relations, especially working-class history, trade union movements, and professionals; gender; race relations and the civil rights movement; social movements more generally; and global inequalities. We found, not surprisingly, that studies based on the stories of people who occupy subordinate social positions have played an especially prominent role in the emergence and development of personal narrative analysis.

Co-authorship presents its own rewards and challenges. We faced the dilemma of how to write in one collective voice even while at times drawing on our individual research findings. We decided to use the first person plural when writing as a collective author: the we in this book is neither royal nor editorial-it's the three of us speaking. When we discuss the work of any one of us, however, we treat it the same way as we treat work by the many other scholars on whose research this book is based-we cite ourselves individually by last name in the usual third person form.

Over the years we have worked on this project, we have received inspiration and assistance in a variety of forms. We all participated in the stimulating intellectual community around Signs: A Journal of Women in Culture and Society when it was edited here at the Center for Advanced Feminist Studies at the University of Minnesota between 1990 and 1995. We are grateful to the Graduate School at the University of Minnesota, the Fund for the Advancement of the Discipline of the American Sociological Association/National Science Foundation, and the Life Course Center in the Minnesota Department of Sociology for financial support. Several graduate assistants provided help and insights-thanks to Martha Easton, Amy Kaler, and Deborah Smith, who were then graduate students in Minnesota's Department of Sociology. We are also appreciative of feedback on chapter drafts from the Minnesota Department of History's Comparative Women's History Workshop, and from panelists and audiences at the Social Science History Association and the American Sociological Association. We would also like to thank Kevin Murphy and Teresa Gowan for their close reading of the entire manuscript. And, finally, we are appreciative of the comments provided by the anonymous external reviewers for Cornell University Press, of the encouragement of our editor, Peter Wissoker, and of the adept support throughout the editorial process provided by Ange Romeo-Hall and Cathi Reinfelder.

Minneapolis, Saint Paul, and Seattle

August 2007 



\section{TELLING STORIES}


